\title{
KUTATÁSI ÉS ALKALMAZÁSI TAPASZTALATOK AZ ADDITÍV GYÁRTÁSBAN
}

\section{RESEARCH AND APPLICATION EXPERIENCES ON ADDITIVE MANUFACTURING}

\author{
Dezső Gergely \\ Nyirregyházi Egyetem, Müszaki és Agrártudományi Intézet, Müszaki Alapozó, Fizika \\ és Gépgyártástechnológia Intézeti Tanszék Cím: 4400, Magyarország, H-4400, \\ Nyíregyháza, Sóstói út, 31/b; Telefon / Fax: +3620599400, dezso.gergely@nye.hu
}

\begin{abstract}
Intensive development of additive manufacturing provides again and again new opportunities for scientific research and engineering applications. The technological variegation, complexity and deep comprehension between technological parameters and built up material's microstructure involves both challenge and several ways of advance. I performed investigations on some tye of additive manufacturing systems. In my work topics of size and shape accuracy, and microscopic structure of digital materials had priority. I also present demonstrative examples of industrial applications.
\end{abstract}

Keywords: additive manufacturing, $3 D$ printing, dimensional accuracy, microstructure, anisotropy

\section{Összefoglalás}

Az additív gyártási technológia intenzív fejlődése újabb és újabb lehetőségeket nyit a tudományos kutatásban és a müszaki alkalmazásokban egyaránt. Fejlődési potenciált és kihívást egyszerre jelent a technológia sokszínűsége, komplexitása és a technológiai paramétereknek az elóállított anyag szerkezetével való szoros összefüggése. Munkám során lehetőségem volt több típusú additív gyártó berendezésen vizsgálatokat végezni. Elsősorban a méretpontosság és alakhelyesség, valamint a technológiai paraméterek és az anyag szerkezetének összefüggéseire vonatkozó vizsgálatokat végeztem. A dolgozatban érdekes ipari alkalmazások bemutatására is sor kerül.

Kulcsszavak: additív gyártás, 3D nyomtatás, méretpontosság, mikroszerkezet, anizotrópia

\section{Bevezetés}

Az additív gyártás napjainkban is intenzíven fejlődő technológiák csoportját jelölő kifejezés. Ugyanennek jelölésére használatosak még a szabadformájú gyártás (freeform fabrication), rétegről rétegre gyártás (layer by layer manufacturing), digitális gyártás (digital manufacturing), 3D nyomtatás, gyors prototípus gyártás (rapid prototyping). Ezek a szavak nagyjából szinonímáknak tekinthetők, általában minden additív gyártási technológiára vonatkoznak. Ezen belül a technológiák különböző csoportjaira is használatosak már speciális elnevezések. Az amerikai ASTM (American Society of Testing and Material) 2010-től olyan szabványokat alkotott, amelyek 7 osztályba sorolják és pontosan megnevezik az additív gyártás technológiáit [1]. A 2012-ben kiadott szabvány visszavonására 2015-ben került sor, ami azt mutatja, 
hogy ennek a szakterületnek az intenzív fejlődése nem csak a kutatókat és a mérnököket, de még a szaknyelv tudósait is kihívások elé állítják.

Az additív gyártás elnevezés egy szembeállítás a szubsztraktív technológiákkal, azt fejezi ki, hogy anyagleválasztás helyett itt anyaghozzáadással történik a gyártás. Érdemes megemlíteni, hogy napjaink csúcstechnikát alkalmazó additív gyártási technológiái mellet ősidők óta használ az emberiség additív módszereket tárgyak előállítására. Ilyen például a kosárfonás, a szövés, épületek építése kövekből vagy téglákból, a nemezelés. Ezen felül arra is gondolhatunk, hogy a növények növekedése, és az állati szervezetek fejlődése is sejtről sejtre, sőt molekuláról molekulára épül fel. Felismerhetjük, hogy az additív tárgyalkotás tudományát az ember hosszú idő óta tanulja, sok esetben a természeti jelenségekröl példát véve. napjaink modern additív gyártási technológiái ugyanakkor rendelkeznek néhány megkülönböztető jeggyel.

A napjainkban használt és fejlesztett additív gyártási technológiákban van néhány közös vonás, amelyek együttese akár ismertetőjegyként is felfogható:

- testmodell: a gyártás kiindulópontja egy 3D CAD testmodell, amely valamilyen szabványos formátumban áll rendelkezésre,

- rétegekre osztás, elektronikus elöfeldolgozás: a testmodellt egy szoftver elektronikus úton elöre megadott vastagságú rétegekre bontja,

- gyártás rétegenként: a rétegekre vonatkozó adatokat az additív gyártó berendezés átveszi, és legyártja azokat egymás után, így előáll a testmodellnek megfelelő valódi szilárd test (alkatrész).

A rétegek legyártásához szükséges utasítássor elkészítése lehet az előfeldolgozó szoftver feladata, de összetettebb rendszerek esetén a gyártó berendezés tartalmazhat külön számítógépet, amely a rétegek geo- metriai adatait fogadva maga készíti el a gyártáshoz szükséges gépi utasítássort. Ennek sok esetben az a fő oka, hogy rendkívül sok adat átvitele szükséges rövid idő alatt, összehangolt módon.

Általában azokat a gyártási technológiákat nevezzük additív gyártásnak, amelyekre igaz a fenti három jellemző. A hasonlóság mellett azonban jelentős eltérések is megfigyelhetők e technológiák között. E különbségek elsősorban a 3. lépés, tehát a rétegek gyártása, anyagi formába öntése területén mutatkoznak meg. Az additív gyártási technológiákat aszerint sorolják osztályokba, csoportokba, illetve aszerint nevezik el azokat, hogy a rétegek gyártása hogyan valósul meg. Ezen a téren igen nagy különbségek vannak, ámulatba ejtő a változatosság, és jelenleg is újabb megoldások látnak napvilágot. Úgy tünik, hogy szinte minden technológiának van létjogosultsága, tehát van olyan terület, ahol előnyösen alkalmazható. Ez annak is köszönhető, hogy a gyártási technológiák számos eltérő szempont szerint optimalizálhatók, mint például a gazdaságosság, a rugalmasság, a teljesítmény, a méretpontosság, esztétikai szempontok és mások, és ezeknek a szempontoknak másmás additív gyártási technológiák felelhetnek meg legjobban.

Napjainkban a porágyas technológiák különös figyelmet kapnak. Ennek egyik oka, hogy ilyen módon szinte minden anyag feldolgozható. [3,5]

Az additív gyártás nem csak a technológia területén jelent jelentős változást, hanem a termékfejlesztés folyamatában is. A CAD testmodellen keresztül soha nem látott szoros kapcsolat alakulhat ki a számítógépes modellezéssel kifejlesztett terv és a megvalósítás között. Egy szimulációs szoftverrel végzett optimalizálás eredménye akár közvetlen bemenete is lehet az additív gyártásnak. [4]

Az additív gyártás 2017-ben előreláthatólag világszerte 7 milliárd dollár összérté- 
kü üzlet lesz, 2020-ra nagyjából 22 milliárd dollárt mutatnak az elörejelzések.

$\mathrm{Az}$ additív gyártó berendezések nem csak a kutató laboratóriumokban, vagy a gyártó cégek kísérleti üzemeiben találhatók meg. Számos cég alkalmaz egyedi vagy tömeggyártási célokra ilyen gépeket, sőt megvásárolhatók otthoni, hobbi célokra is bizonyos típusok. Mi több, ügyes kezü amatőrök néhány előre gyártott hardver és szoftver eszközt felhasználva ma már elkészíthetik saját 3D nyomtatójukat is.

\section{Egy anyagszórásos technológia}

A Nyíregyházi Egyetem Additív Gyártás Laboratóriuma rendelkezik egy OBJET Eden $350 \mathrm{~V}$ típusú additív gyártó berendezéssel. Az a technológia, amit megvalósít az anyagszórásos (material jetting) technológiák körébe sorolható, de saját megkülönböztető névvel is rendelkezik: polyjet.

Fotopolimer mügyantából történik a gyártás. Ez kezdetben folyékony halmazállapotú, szivattyúzással jut a szóró egységbe, amely nyolc fejet tartalmaz. Minden fej 96 db nyílással rendelkezik, amelyeken keresztül piezoelektromos kristályok lövik ki az 5 mikrométer nagyságú folyadékcseppeket.

A szóró egység két oldalán folyamatosan világít két ultraibolya lámpa. Az ultraibolya fény hatására a mügyanta rövid idő alatt megkeményedik. (1-3. ábrák)

Kétféle anyagot használ a rendszer. A modellanyagból alakul ki a gyártmány. A támaszanyag feladata, hogy a folyékony modellanyagot a helyén tartsa addig, amíg megkeményedik. A támaszanyag mechanikai és kémiai úton eltávolítható.

\section{Méretpontosság}

Az additív gyártás egyik fontos tulajdonsága a méretpontosság. Az OBJET berendezés által megvalósított technológia vizsgálatára $3 \mathrm{db}$ 20×20×20 mm névleges méretü, kocka alakú próbatestet készítettünk.

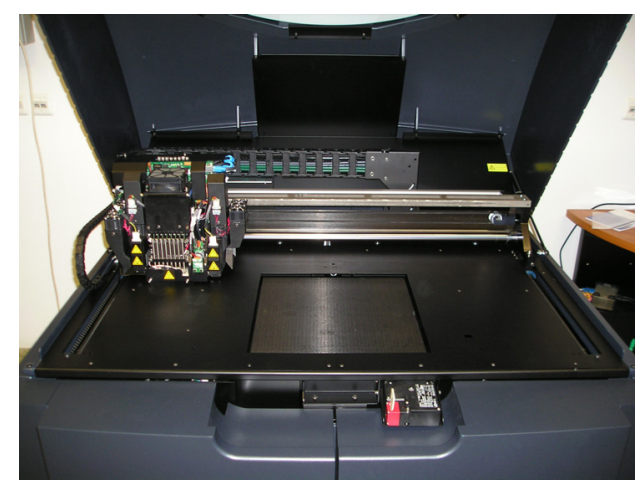

1. ábra. Az OBJET Eden $350 \mathrm{~V}$ berendezés

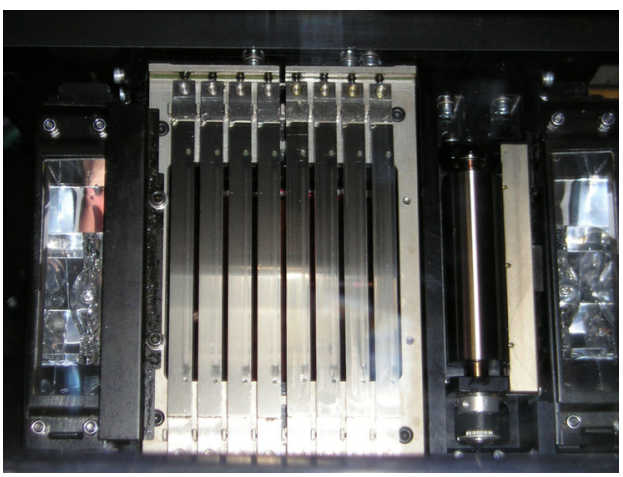

2. ábra. A szóró egység a 8 nyomtatófejjel és a két UV lámpával

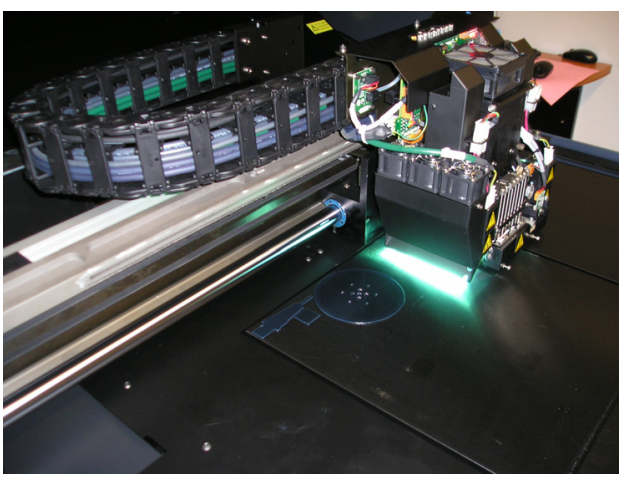

3. ábra. A nyomtató munka közben: a fej a tengely irányában mozog, a munkaasztal lefelé, a lámpák folyamatosan világitanak 
Megmértük a szemközti oldallapok távolságát 5-5 ponton. Az adatokat összesítve ki lehetett mutatni a következőket:

- Minden egyes mérés esetén a mért távolság és a névleges $20 \mathrm{~mm}$ méret közötti eltérés kisebb volt, mint $0.1 \mathrm{~mm}$, ami megegyezik a gyártó cég állításával.

- A szóró egység mozgására vízszintesen merőleges irányban a mért adatok szórása egy nagyságrenddel nagyobb volt, mint a másik két irányban.

- A szóró egység mozgásának irányában az oldallapok távolsága statisztikailag szignifikánsan nagyobb volt a névleges értéknél, míg függőleges irányban szignifikánsan kisebb.

Ezek a megfigyelések összefüggésbe hozhatók a gyártási technológiával. Miközben a mügyanta rétegről rétegre való kiszórása zajlik, időnként egy henger alakú simítógörgő fut végig a gyártott test aktuális szabad felső felületén. Bármilyen pontosan végzi feladatát ez lefelé tömörítő és a mozgás irányában nyújtó hatást fejt ki. A hanger mozgásának kifinomultságát mutatja az a tény, hogy a mozgásirányra merőlegesen már nem lehet szignifikáns eltérést tapasztalni a névleges mérettől, tehát a henger nem nyomja le a felületet, hanem inkább kicsiny vonalmenti húzó hatást fejt ki rá, miközben végigfut azon, annak ellenére, hogy forog eközben. A részben megkeményedett modellanyag azonban még nem elég rugalmas ahhoz, hogy akár még ezt a csekély alakváltozást is megszüntesse. Az általunk készített próbatestek esetén ez 2040 mikrométer mérethibát eredményezett ebben az irányban.

Mind a technológia, mind a méretpontosság irányfüggése arra utal, hogy a gyártmány egyéb tulajdonságai is irányfüggést, anizotrópiát mutathatnak.

\section{4. Ütőmunka}

Szabványos próbatesteket készítettünk az additív gyártó berendezésünkkel úgy, hogy a különböző mintasorozatok hossztengelyei a tér három irányába mutassanak [6]. Ezt követően Charpy-féle töréstesztet hajtottunk végre azokon, megmérve a mintákon végzett ütőmunkát.

Az ütőmunka értékek a szóró egység mozgásának irányába eső tengellyel nyomtatott próbatestek esetén szignifikánsan nagyobbnak mutatkoztak a másik két irányba eső tengelyü próbatestekre kapott eredményeknél. Kiderült, hogy az ütőmunka is irányfüggő.

A törésteszt az ütőmunka megmérésén túl egy másik vizsgálatra is lehetőséget nyitott: megvizsgálhattuk a töretet, ami feltárta a törésnek kitett részek szerkezetét, ezáltal részben feltárva azt, hogyan viselkedik a modellanyagunk dinamikai igénybevételek hatására.

A felületek mikroszkópos megfigyelését Hitachi SU-1050 pásztázó elektronmikroszkóppal végeztük el. Az eszköz gyorsító feszültsége $15 \mathrm{kV}$, nagyítása 10 és 10000 között változtatható, legfeljebb $153 \mathrm{~mm}$ méretű mintát képes befogadni. A mügyanta anyagú testek úgy vizsgálhatók elektronmikroszkóppal, ha elötte igen vékony arany bevonatot képezünk rajta.

Az elektronmikroszkópos felvételeknek nem csak az erős nagyítás az előnye, hanem a nagy mélységélesség is. Ez lehetővé teszi azt, hogy vizuálisan is megfigyeléseket tegyünk a felszín morfológiai jellemzőire vonatkozóan.

Az eltört próbatesteken számos különböző eredetü felület figyelhető meg. Egyrészt láthatók a gyártással eredetileg kialakított felületek. Meg lehetett figyelni, hogy ezeknek szerkezete és érdessége erősen függ az orientációtól. Másrészt a töret felszínén is megfigyeléseket lehet végezni. Több tartomány különíthető el, és a felületek alaktani sajátosságai ismét függenek a próbatest tengelyének irányításától. A következő ábrák néhány illusztratív példát mutatnak. 


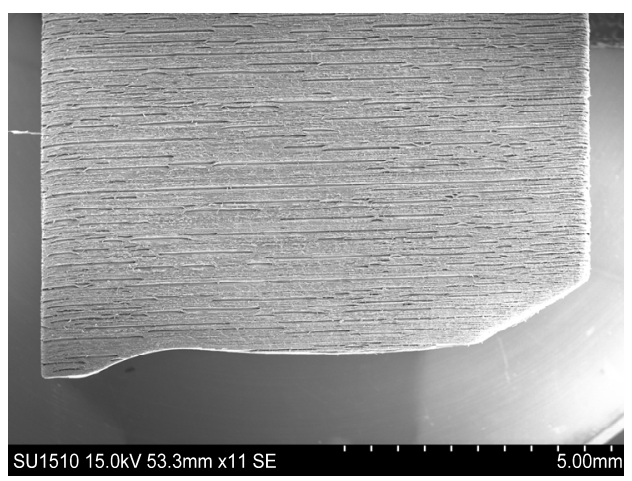

4. ábra. A töret felülnézete, jobb oldalon látható a bemetszés egyik fele $(N=11 x)$

A 4. ábra olyan eltört próbatestet mutat, amelyben a hossztengelyre merölegesek a gyártási rétegek síkjai $(\mathrm{N}=11 \mathrm{x})$. Ugyanennek a próbatestnek egy részletét erősebb nagyításban $(\mathrm{N}=100 \mathrm{x})$ mutatja az 5. ábra, amelynek bal oldalán a gyártott felszín látható, a rétegek szélei is jól kivehetők, a bal oldalon a töret felületén a rétegek felszakadásával kialakuló lépcsős felület figyelhető meg.

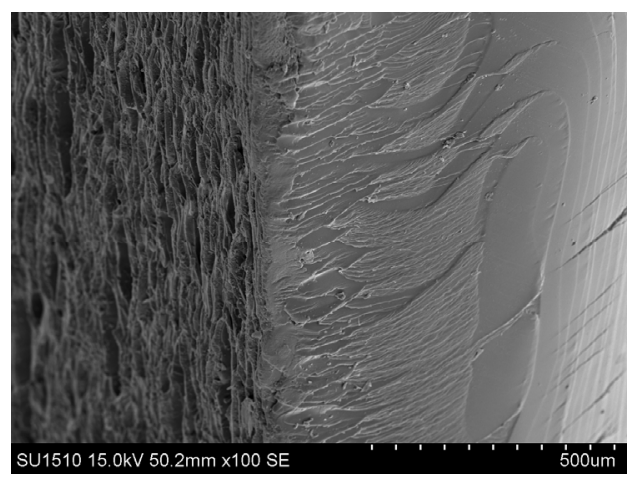

5. ábra. $A$ 4. ábrán mutatott minta részletet erösebb nagyitásban $(N=100 x)$

A 6. ábra szemlélteti azt, hogy a felületek minősége és alakzatai mennyire eltérnek az irányítás függvényében. A felülről simított felület egységes, látható rajta a simítóhenger mozgásának nyoma. A gyártáskor

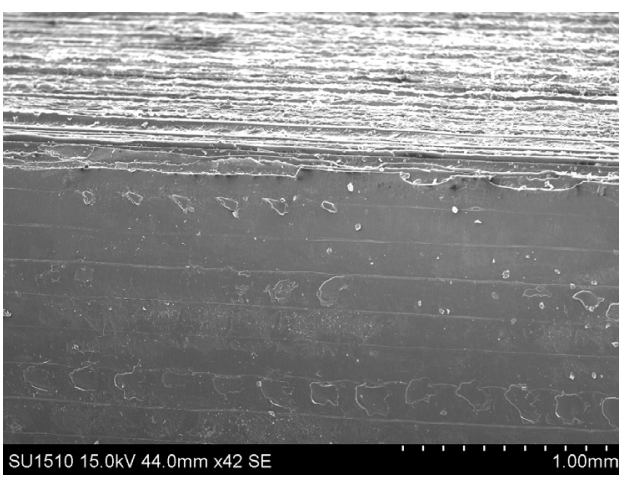

6. ábra. Az ábra alsó fele mutatja a gyártáskor simitott, felsö felületet $(N=40 x)$

függőleges felület olyan, mint egy kártyapakli oldalnézetből, a rétegek szélei figyelhetők meg rajta (a 6. ábra felső részén, az 5. ábra bal oldalán, vagy az 1. ábrán mindenütt, de ott kisebb a nagyítás).

\section{Alkalmazások}

Laboratóriumunkat elsősorban olyan partnerek keresik fel, akik prototípust szeretnének készíteni. A prototípus készítésének elsődleges célja az szokott lenni, hogy bemutassák azt megrendelöiknek, vagy a cégen belüli fejlesztőknek.

Az egyik partnerünk kozmetikai készítmények számára gyárt tégelyeket. Több alkalommal keresett fel bennünket újonnan kifejlesztett termékek porototípusainak gyártására. Ebben a feladatban az volt a különleges, hogy a tégely falvastagsága 0.6 $\mathrm{mm}$ volt. Elkészítettük a fedelét is, amely menettel csatlakozott az alsó részhez. A prototípus esztétikai és funkcionális szempontból egyaránt megelégedésére szolgált a partnernek.

Egy nemzetközi cégcsoport magyarországi leányvállalatánál fejlesztést hajtottak végre, aminek eredményeképpen egy régi terméket újabb változatra lehetett cserélni. Ennek prezentációjához készítettünk prototípusokat. A fejlesztés különlegessége az volt, hogy a két félből álló termék darabjait 
pattintással kellett egyesíteni. Itt két követelmény teljesítése volt szükséges: a kényelmes, nem túl nagy erővel történő öszszepattintás, utána pedig a szoros, megbízható együttmaradás. Mindkettőt sikeresen teljesítette az általunk készített prototípus. Később tájékoztatást kaptunk arról, hogy a cégvezetés előtti sikeres prezentációt nagyban segítette a prototípus, és a fejlesztést elfogadták.

\section{Következtetések, kilátások}

Tapasztalataink és a szakirodalomból kivehető nemzetközi trendek egyaránt azt mutatják, hogy az additív gyártás intenzív fejlődése jelenleg is tart, és a jövőben is fontos eredményekre van kilátás.

\section{Szakirodalmi hivatkozások}

[1] Standard Terminology for Additive Manufacturing Technologies, ASTM, F279212a, visszavonva 2015-ben, http://web.mit.edu/2.810/www/files/readings/ AdditiveManufacturingTerminology.pdf

[2] L. Colombus: 2015 roundup of $3 D$ printing market forecasts and estimates, https://www.forbes.com/sites/louiscolum bus/2015/03/31/2015-roundup-of-3d- printing-market-forecasts-andestimates/\#31f16c131b30

[3] M. Markl, C. Körner: Multi-scale modeling of power-bed-based additive manufacturing, Annual Review of Material research, 46 (2016) pp. 1-34. DOI: 10.1146/annurev-matsci-070115032158

[4] S. Guessasma et al: Challenges of additive manufacturing technologies from an optimization perspective, Int. J. Simul. Multisci. Des. Optim. 2015, 6, A9 DOI: $10.1051 / \mathrm{smdo} / 2016001$

[5] G. Buican, G. Oancea, A. Manolescu: Remanufacturing damaged parts using selective laser melting technology, Applied Mechanics and Materials Vol 693 (2014) pp 285-290 doi:10.4028/www.scientific.net/AMM.6 93.285

[6] Gergely Dezső, Ferenc Szigeti: Microscopic Investigation on Material Stucture of Broken Additively Manufactured Parts, Modern Technologies in Manufacturing, 2015, vol 808, p 175-181, ISBN-13: 978-3-03835-653-0 http://www.scientific.net/AMM.808 